\title{
Is Albanian Legal Framework on Labor Relations Enough Sufficient to Protect from Discrimination Based on Sexual Orientation?
}

\author{
Ph. D. Candidate Adisa Teliti \\ Lecturer, Faculty of Education, University “Aleksandër Moisiu”, Durrës \\ adisatelitigmail.com
}

\section{Doi:10.5901/mjss.2014.v5n20p447}

\begin{abstract}
The recognition, the respect for human rights and fundamental freedoms, the protection of human dignity and personality are the basic principles on which is based on the welfare state and the rule of law. This principle imposes the Albanian state to develop and adopt a comprehensive legal framework, so that any individual or group of individuals to have effectively these constitutional and legal rights. This article analyzes the legal framework for protection from discrimination based on sexual orientation in society. Its main focus is the protection from discrimination based on sexual orientation (LGBT community) in their labor relations, in their role as an employee and an employer. The article offers a general view to the evolution of the legal framework, since the first constitutional provisions in this field up to the lastest provisions related to the obligations of the Albanian state derived from memberships in various organizations focusing on the human rights and freedoms. In the end, the article will give the conclusions and recommendations related to the absences of our legal framework on current protection from sexual orientation discrimination on labor relations.
\end{abstract}

Keywords: protection against discrimination, sexual orientation, labor relations, the principle of equality, $L_{G B T^{1}}$

\section{Introduction}

Social economic development has always accompanied changes of human beings. Different points of view have been integrated with social movements. The changes of sexual orientation have raised a lot of questions and problems which the society should act.

Labor relations are one of the most important relations in the everyday life. Labor is not only seen as a manner of living, but also as a way to interact with others. The new forms of discrimination are part of our everyday life and are been expressed in different ways. One of the most problematic forms of discrimination is the sexual orientation. The LGBT movements ${ }^{2}$ have started in Albania at the 1994, but they have not been so confidential and decisive. It is worth mentioning that in Albania until 2001, homosexuality was considered a crime envisaged by Article 116 of the Criminal Code. Homosexuality was decriminalized in 2001. (Criminal Code )

The Albanian legislation has made different provision in protection the human rights. The principle of equality and non discrimination is clearly affirmed in the key acts, such as: Constitution, Labor Code etc.

Even though, these acts protect every one and offer the same protection to each human being, the discrimination in labor relations exists. The most problem is the discrimination against the employers. It is very difficult to analyze this problem from the point of view of an employee.

The discrimination based on sexual orientation is a new form of discrimination in Albania. This is the main reason why the acts that are part of this article, do not have an expressed protection for this community.

The doctrine and the jurisprudence should be very active and open minded, in order to offer a great protection and real one for this community.

Review of Gender Directive the EU limits in 2010 represents one opportunity to include "gender identity" in order to direct discrimination as a basis in future directives to the EU and in this way to exceed the actual restrictions in including of all members of $\mathrm{LGBT}^{3}$.

\footnotetext{
${ }^{1}$ The term LGBT is the words collective acronym lesbian, gay, bisexual and transgender. The term LGBT used in the international level. LGB has deals with a gender sexual orientation (LG) or to both (B). While letter T has deals with gender identity. Often the term is used LGBTIQ. Letters I (intersex) intersex used for persons, a general term that refers to the top of which people have born with a reproductive or sexual anatomy that does not seem typical definition was also adjusted, woman or male. And the most recent term (Questioning) with letter $Q$ which is used for people used for people who do not yet understand for sexual orientation or gender identity to them.

2 The organization "Gay Albania" was the first organization in the history of Albania, which will work for the rights of LGBT community.

3 Directive 2006/54/EC of the European Parliament, 5 July 2006 on implementing the principle of equal opportunities and equal treatment between men and women in relation to employment issues (revised), pg. 23
} 
The article analyzes the most important acts in the field of labor relations and their level of protection for the LGBT community ${ }^{4}$.

\section{Constitution}

The Constitution is the fundamental act of a State which regulates especially the rights and fundamental freedoms. The Constitution also affirmed the basic principles on which is created, works and is organized Albanian state. Since its preamble affirms the obligation of state to recognize and respect the rights and fundamental freedoms and the protection of human dignity and personality.

Article 3 of the Constitution provides: "... human dignity, rights and freedoms, social justice ... pluralism, and coexistence and understanding of Albanians with minorities are the bases of this state, who has the duty to respect and protect them ". So, the principle of respecting and protecting human dignity is strongly affirmed by the Constitution and is closely related to human rights and fundamental freedoms. Respect for human dignity serves as a basis for interpreting without which human freedom cannot be applied.

Currently there is no definition of Albanian jurisprudence in relation to the principle of respecting and protecting human dignity. Although the Constitution of Albania, unlike some other formulations of democratic constitutions, has given human dignity, clear the way for a fundamental constitutional principle. It serves as a basis for interpreting the Constitution and all parts of his respect and protection, all underlying legal system. (Omari, Luan Anastasi, Aurela, 2010)

The principle of equality in the Constitution of the Republic of Albania is formulated in the classic version of this principle, the equality of all before the law ${ }^{5}$. This principle is melted with the principle of protection from discrimination. The legislator has listed in a non- exhaustive ${ }^{6}$ the reasons which make the basis of discrimination.

One of the newer forms of discrimination in Albanian society is discrimination based on sexual orientation. The existence of sexual preference against same sex or both sexes, constitutes a form of violation of someone's life by others who conceived socially acceptable, heterosexual. Albanian Constitution adopted in 1998 did not make the necessary provisions for new forms of popular discrimination century. XXI.

For this, the law enforcement must interpret in order to expand discrimination based on sex ${ }^{7}$, including on this even discrimination based on sexual orientation. Gender identity is a legal fact that is related to a number of legal consequences as marriage, retirement age, protection against discrimination, segregation by sex environments, etc. gender identity in the Republic of Albania is defined in the act of birth, signed by medical staff that assists childbirth. The only authority that can change the data is the court.

If persons changed gender identity a number of consequences, as follows:

a. Name-sex changes bring the effect of changing the name, which affects all documents.

b. Marriage - sex change makes possible marriage with the other sex. A person who has changed sex, but is not reflected in the documentation, cannot marry the other gender (currently with same sex marriage is banned in Albania).

c. Retirement age-sex change brings a change in retirement age, which for women is lower.

d. Employment-sex change brines the benefit of a different approach to work, because women have special protection by the Labor Code.

In this issue the problem arises exactly on the legal issue of changing the birth act. If the act is complied on a regular basis and reflects the correct data at the time of birth, it remains unchanged even though the persons may have changed gender afterwards.

With this way of thinking, the Albanian lawmaker takes into considerations:

a. Gender identity is definable only in birth.

b. Gender identity relates only to the biological fact of gender, taking for granted that the person will definitely feel like a member of that gender even when grown up.

\footnotetext{
${ }^{4}$ The structure of this article is based on the hierarchy of the legal acts, according to the provisions of article 116 of Albanian Constitution.

${ }^{5}$ Article 18 of the Constitution provides: "1. All are equal before the law. 2. Nobody can be discriminated against on grounds such as gender, race, religion, ethnicity, language, political opinions, religious or philosophical beliefs, economic, educational, social, or ancestry. 3. Nobody shall be discriminated against for reasons mentioned in paragraph 2, unless there a reasonable and objective justification.

${ }^{6}$ Although the legislator has listed reasons such as: gender, race, religion, philosophical, social ... etc., and why so exhaustive, the list should be interpreted in a manner that is considered not exhaustive. This is because the Constitution as the fundamental act of a State requires a qualified majority to be changed. In this way practitioners and interpreters of the law within this list should also include new forms of discrimination. In this way, the Constitution would not be subject to amendments that change whenever the political, economic and social realities in Albanian.

${ }^{7}$ Gender refer to psychological and social meanings that accompany being biologically male or female. Sexual orientation term is used to describe romantic attraction, emotional or sexual abuse of a person to another person.

${ }^{8}$ http://www.pinkembassy.al/sites/default/files/uploade/2011\%20Legjislacioni\%20Nderkombetar\%20dhe\%20Kombetar\%20ne\%20Mbrotje\%20te\%20te\%20Drejtave\%20te\%20Komunit etit\%20LGBT.pdf
} 
c. Gender identity and gender is immutable.

Regarding these considerations, if exposed to a logical debate and confrontation of evidence, other conclusions can be reached. So we could briefly acknowledge that:

a. First, gender identity is determined at birth and takes into account only the genitals, but does not take into account any other influential element, such as hormonal balance. It is scientifically proven that it is possible to change gender; it is even possible to perform hormonal therapy which brings the necessary physiological changes, which are fully accepted by the coroner.

b. Second, gender identity is not just a matter of objective side, but there is also a subjective side. There is no guarantee that a new-born child will feel according to its gender. The LGBT community itself is living proof of this reality.

c. Third, gender is changeable. Medicine allows such a thing. (Karen, E. Lovaas, John, P. Elia, Gust, A. Jep, 2006)

In these conditions, the legislator has not provided any situation regarding gender identity, leaving in this case not a legal blockade, but a legal vacuum.

The enjoyment of rights and fundamental freedoms is closely related to the concept of man as natural and biological being, not limited to sexual orientation.

Constitution in Articles 49, 50.51 do recognizes the right to every person to earn livelihoods through legal work, the right to join labor organizations or the right to strike in the case of employer-employee disputes. This means that the state does not restrict the right to be employer or employee on the basis of sexual orientation. The state is responsible for complying the general principles and constitutional rules in the field of labor. For example, it fully engage and its responsible for the implementation of the principle of equality in labor relations. (Omari, Luan Anastasi, Aurela, 2010).

In conclusion, we can say that the constitutional provisions regarding the protection from discrimination on the basis of sexual orientation even they are not direct, are full, knowing their right every member of the LGBT community, to be in the role of employer and employee, and freely exercise his rights and duties in labor relations.

\section{International Agreements}

LGBT community rights are protected and guaranteed by diverse international instruments. Albania has ratified and signed a number of important conventions which guarantee protection from discrimination to people who are part of this community. Such instruments have the main focus and labeling due to homophobia in the labor relations.

\subsection{Stabilization and Association Agreement ${ }^{9}$}

In Title V Stabilization and Association Agreement defines institutional and legal obligation must meet Albanian state regarding the free movement of workers and capital, as two of the freedoms on the basis of which the European Community was founded .Albanian state engages to respect the rights of every Albanian citizen who is lawfully employed in the territory of every Member State of the European Union, eliminating each form of discrimination. Albanian state also assumes under bilateral agreements with each of the Member States to recognize and respect each employee insurance period for pension purposes injury, or disability. This duty applies on the Albanian state even when a citizen of a member state is legally employed in the territory of the Republic of Albania ${ }^{10}$.

These predictions impose liability before the European Union to take all necessary steps in order to realistically be implemented and recognized the rights of Albanian employees working in one of the Member States of the European Union or in the case where an employee of a Member State of the European Union is employed in the territory of the state.

\subsection{Convention}

Among all these conventions, the most important related to our topic are:

1. The European Convention on Human Rights, which obliges the state to take concrete and effective measures to guarantee every right to this community. Article 14 of the Convention prohibits any form of discrimination and provides that: "The enjoyment of the rights and freedoms set forth in this Convention shall be secured

\footnotetext{
${ }_{9}^{9}$ Full text is available at: $h$ ttp://www.integrimi.gov.al/al/dokumenta/dokumente-strategjike/marreveshja-e-stabilizim-asociimit\&page=1
}

10 For further information read article 46-48 of SAA. 
without discrimination on any ground such as sex, race, color, language, religion, political or other opinion, national or social origin, association with a national minority, property, birth or other status"11.

2. Another convention that protects and guarantees the rights of this community is the Convention on the Elimination of All Forms of Discrimination against Women ${ }^{12}$.

This Convention on the fifth Section provides that: "States Parties shall take all appropriate measures:

To modify the social and cultural patterns of conduct of men and women, with a view to achieving the elimination of prejudices and customary and all other practices which are based on the idea of the inferiority or the superiority of either of the sexes or on stereotyped roles for men and women" ${ }^{13}$.

Also the Amendment of Article 8 of the International Convention on the Elimination of All Forms of Racial Discrimination in New York on 15 January 1992 is an important instrument for guaranteeing protection of the rights of LGBT.

\section{Labor Code}

Work is a conscious activity and voluntary, naturally, but it's hard, because it contains effort for creating or processing a work useful, tangible or intangible (intellectual). (Cela, 2003) This means that the work is a phenomenon that establishes a relationship between the two parties, between employer and employee. The employer is the party that has available cash and materials, while the employee is a person who makes available to employers his service and his physical and mental abilities.

Labor Code is the main law governing labor relations in the Republic of Albania, including the rights and obligations of employers and employees, contract labor and its elements, cases of labor contract, the union activity etc... According to Article 9/ point 3 of the Labor Code, "with employment and profession is understood professional orientation and training, occupation busyness and in different professions, and employment conditions related to workload, performance, reward, social assistance, discipline or termination of the employment contrac"t. According to these forecast employment and occupation is a right that is recognized to each person on the basis of his own free will. Despite his sexual orientation, no one can be affected in his desire and willingness to learn and practice a profession or to start a job.

Labor Code prohibits every kind of discrimination in hiring at the job and profession. This is a prediction of law, which goes into full compliance with constitutional provisions. But what is discrimination? Discrimination means any distinction, exclusion or preference based on race, color, sex, age, religion, political beliefs, national origin, ancestry, social, family, physical or mental disability that affects an individual's right to be the and equal treatment in employment.

Labor Code was adopted by Law no. 7961 dated 12.07.1995, subject to change several times. In these conditions referring socio-economic changes, this provision should be interpreted in order to expand. Listing a number of factors that make up the basis of direct discrimination and lack of direct factor like sexual orientation does not a basis to deny the existence of such a form of discrimination. Also, the prohibition of discrimination based on sexual orientation does not mean he has not the protection of the Albanian state. Any person who is discriminated against because of sexual orientation in hiring, in being at work or in the exercise of a profession, should enjoy protection by the Labor Code. Although this act has undergone changes several times, this form of discrimination has not found the right coverage. Will these people that using the proper tools will require the direct protection of Article 9 of this code. The Labor Code also recognizes the concept of positive discrimination ${ }^{14}$, which, specific requirements for a particular job does not constitute a basis for discrimination ${ }^{15}$. (Kudret Cela Paskal Haxhi, 2002)

\section{Law "On Discrimination Protection" 16}

Law "On Discrimination Protection" was a necessity of time to be approved. New forms of direct discrimination and deficiencies of their direct forecasts on basis acts related to employment (as evidenced in the cases above) forced the

\footnotetext{
1 Article 14 of the European Convention on Human Rights, Rome, 4.XI.1950, Albania ratified by Law No. 8137, dated 31.7.1996. Full text is available at: http://www.echr.coe.int/Documents/Convention_SQI.pdf

1212 This convention is ratified by law no. 7767, dated 09.11.1993.

13 International Convention on the Elimination of All Forms of Racial Discrimination. New York, 7 March 1966, acceded in 1994. Full text is available at: http://www.unmikonline.org/regulations/unmikgazette/03albanian/Ahri/AConEliminationAllFormsDiscriminationAgainstWomen.pdf

${ }_{14}$ Positive discrimination is the process for preferential treatment, especially in employment, minority groups of society that are biased in the past. It should be noted that "preferential treatment" does not mean that these individuals will automatically be preferred candidates compared to another, but rather that both candidates should be considered on a similar level.

15 "Article 9 points 2 of the Labor Code provides: "distinctions, exclusions or preferences required for a particular job are not considered discrimination. Special protective measures for employees provided by this Code by the Council of Ministers or the collective contract are not considered to be discriminating".

16 Law no.10 221, dated 04.02.2010 "On discrimination protection".
} 
Albanian legislator to enact a specific law on protection from discrimination.

Scope of the Law "On Discrimination Protection" is the implementation and observance of the principle of equality regarding gender identity, sexual orientation, genetic predisposition, disability, belonging to a specific group or with other cause in the field of education, employment, and the establishment and effective functioning of state structures for application in the most effective way of this principle. Law has been very open listing a variety of causes on the basis of which discrimination arises, but leaving open the list. So any new form of discrimination is protected by this law, surpassing the "constraints" in the Constitution and the Labor Code ${ }^{17}$.

This law aims to regulate issues that may arise as a result of his violation, which mention the issues facing the LGBT community. This means that these people have equality before the law, equality of opportunities and their possibilities to be employer or employee and effective protection against any form of discrimination. Although the law was passed in the spirit of controversy with a series of social, moral or cultural, its effectiveness has not been seen yet in practice. It is worth mentioning that in Albania until 2001, homosexuality was considered a crime envisaged by Article 116 of the Criminal Code. Homosexuality was decriminalized in $2001^{18}$.

Employment as an important aspect in the lives of every individual is treated with the same importance and in this law. Law Article 12-15 makes all necessary arrangements regarding employment process, rights and responsibilities that belong to the employer, and the employee, the institutions that have their object of protection from discrimination, while also offering ways solving problems if facing a form of discrimination, both directly and indirectly ${ }^{19}$.

Protection from discrimination extends its effects throughout all the employment process, since the declaration of the job vacancies, recruitment and treatment of employees in the workplace, the employer's conduct during disciplinary process, dismissal or termination of the contract of employment. Discrimination on grounds of sexual orientation, creation and enterprise of all effective measures is conceived in the context of the obligations of the employer and employee rights. Legal labor relationship ${ }^{20}$ as a bilateral legal relation produces mutual rights and obligations of employers and employees. In the case of discrimination based on sexual orientation, as well as for any other form of discrimination, the employer has only duties to prevent and eliminate them in work environments ${ }^{21}$.

In the context of employee protection from discrimination on the basis of sexual orientation is his right in labor relations, especially the rights arising from the reward to work ${ }^{22}$.

Albanian legislator has provided that every employee has the right to complain to the employer, to the Commissioner for Protection from Discrimination or in court, if it believes has suffered discrimination. This means that the legislator has provided that exists in labor relations principle of discrimination based on sexual orientation, and presented how the law enforcer reacted in certain cases to the existence of this kind of discrimination, and mentioned decisions of the Commissioner for protection from Discrimination. Worth mentioning Decision No. 58 dated 08.05 .2013 of the Commissioner for Protection from Discrimination on which Pink Embassy Pro LGBT Albania organizations had claimed that writing published in the Daily Independent newspaper "English" dated 23 March 2013, Z.A L, had an open content discriminatory, homophobic and misleading to the community and the LGBT movement in Albania. After reviewing the complaint based on facts and laws had actually resulted discriminatory behavior, and taking appropriate punitive measures ${ }^{23}$.

\section{Other Legislative Measures}

\subsection{National Strategy for Gender Equality and Reduce Gender Based Violence and Domestic Violence 2011-201524}

The Albanian government has undertaken to promote the principle of gender equality, strengthening the legal and institutional hedging instruments to ensure gender policies at all levels of government. Drafting and approval of this

\footnotetext{
17 Under this law, discrimination is any distinction, exclusion, restriction or preference based on any cause mentioned in Article 1 of this law, which has the purpose or effect of hindering or making it impossible to exercise in the same way with others, rights fundamental freedoms recognized by the Constitution of the Republic of Albania, with international acts ratified by the Republic of Albania, as well as applicable laws.

${ }^{18}$ Changes made to the Criminal Code, under Law no. 8733, dated 24.01.2001.

${ }^{19}$ Direct discrimination occurs when a person or a group of persons because of the characteristic of the discriminated placed or is placed in a disadvantageous position. So the person is a personal trait reason (cause) for unequal action against him. While direct discrimination has to do with the different approach to persons in similar situations, indirect discrimination has to do with the same access to persons who are in different situations. In other words, direct discrimination has to do with different approaches (unfavorable), but not to indirect discrimination approaches differ, but the consequences are distinguished, which are disproportionately uncomfortable compared to a specific group, widely for individuals who belong to that group.

20 Legal labor relations are relations with reward, of which derive rights and obligations provided for in the contract of employment.

${ }^{21}$ Article 13, Law No. 10 221, dated 04.02.2010 "On Discrimination Protection".

22 Article 15, Law No. 10 221, dated 04.02.2010 "On Discrimination Protection".

${ }^{23}$ The full decision is: http://kmd.al/skedaret/1374673668-Vendim_58.pdf

${ }^{24}$ Approved by the Council of Ministers, Decision no. 573, dated 16.06.2011. Full text is available: http://www.mpcs.gov.al/dpshb/images/stories/dpshb/skbgj-rdhbgjdhf2011-2015180213.pdf
} 
strategy was a necessity of the time, but also in the context of all the obligations of the Albanian state derived from international agreements aimed at promoting basic human rights and the principle of non-discrimination. The action plan of this strategy is conceived on two main areas, gender equality and reduce gender-based violence.

Under this strategy, gender equality means equal access to and control over resources and benefits, equal participation in political decision-making and equality by law for men and women ${ }^{25}$.

Ministry of Labor, Social Affairs and Equal Opportunities is committed to take concrete action, which effectively enable participation and equal protection, regardless of sex, gender identity, (dis) ability, age or social origin.

From strategy through monitoring that was done, it's been noticed that the media is still dominated by sexist language, gender stereotypes and prejudices about women. Albanian media remains problematic for not only reflection of reality masculine society and distorts gender roles, but also the fact that the Albanian reality is reflected in the structure of the construction and operation of the media ${ }^{26}$.

\subsection{Social Sector Protection Strategy 2007-201327}

Ministry of Labor, Social Affairs and Equal Opportunities in August 2007 adopted the Social Protection Sector Strategy. This strategy present government horizontal policies for poverty reduction and the fight against social exclusion. Own strategy aimed at completing its review and further in accordance with the basic policies of the government and other obligations arising from the approximation of legislation with the European one. This strategy is coordinated in accordance with crosscutting other documents, such as Strategy on Gender Equality and Domestic Violence.

One of the strategic priority of this document is to provide social protection for each individual in need, regardless of gender, origin, religion, age, disability or other specific. Although the strategy has not explicitly considered for the provision of social protection regardless of sexual orientation should say that this is not prohibited. Any individual regardless any cause that makes it specific in relation to the rest of society has the right to benefit from social assistance or any other action. This concept is expressed as an obligation of social service providers, who are obliged to respect the rights, dignity, views and particularities beneficiaries of services from planning to implementation.

The strategy has as its vision for social inclusion of marginalized groups and improving gender equality. It should be emphasized that this strategy have completed effects. So, the Ministry of Social Welfare and Youth must adopt new strategy for social protection and including new forms of discrimination, especially providing social protection for the LGBT community.

\section{Conclusions}

$>$ Albanian legal framework on labor relations is in accordance with the international conceptions and organizations, that our state is part of.

> Albanian Constitution, is the most important act, affirms the protection from discrimination, but it doesn't express clearly the discrimination based on sexual orientation.

$>$ Labor Code is the most important act that regulates labor relations. The most important principle in this relation is the protection against discrimination.

$>$ The necessity to affirm the protection of LGBT community in labor relations raises from the international conventions, from the membership in different international organization.

$>$ The most important movement of our state in order to fulfill its obligation is the approvment of the law no. 10221, dated 04.02.2010 "On discrimination protection". This is the first law in whole legislative process that clearly affirms the protection from discrimination based on sexual orientation in labor relations and not only!

Even though, our state through its institutions has approved some strategies in order to offer protection from different forms of discrimination, the sexual orientation its only mention, without offering concrete measures.

\footnotetext{
${ }^{25}$ National Strategy for Gender Equality and Reduce Gender Based Violence and Domestic Violence 2011-2015, pg. 11. Also part of the strategy stipulates that all social, economic and political conditions in Albania should be and gender mainstreaming. According to her gender mainstreaming is the process that ensures gender perspective and gender equality should aim to be at the center of all activities, policy development, research, advocacy / dialogue, legislation, resource allocation and planning, implementation and monitoring of programs and projects to promote and achieve gender equality. Such a strategy not only ensures the achievement of sustainable development through the use of full human potential of the country, but also ensures that all social groups to enjoy these achievements.

$26 \mathrm{lbid}$ pg. 55-58.

${ }_{27}$ Full text is available: http://www.crca.al/sites/default/files/publications/Strategjia_sektoriale_e_mbrojtjes_sociale2007-2013.pdf
} 


\section{Recommendations}

De strongly reccomand the legislator to add as on important and new form of discrimination, that based on sexual orientation.

$>$ Informing staff about the existence of the LGBT community in their work and stimulate the creation of a safe environment to work, without violence offending, social exclusion or inhuman treatment. Their information consists of protection that these persons are guaranteed by law and punitive measures in case of violation.

$>$ Itself LGBT community should undertake awareness campaigns to public and private administrations to involve these people at work, their equal treatment.

$>$ LGBT community in Albania must carry out studies on the current status of this community relations work, as are involved and whether their cases of discrimination based on their sexual orientation.

$>$ The state should give more importance on education focus on sexual orientation, a process that would start in the early learning.

> The LGBT community should be more active in the field of human rights and awareness.

$>$ We strongly recommend a big collaboration between associations and the state.

\section{References}

Albanian Constitution

Article 14 of the European Convention on Human Rights, Rome, 4.XI.1950, Albania ratified by Law No. 8137, dated 31.7.1996.

Cela, Kudret Haxhi, Paskal. (2002). E drejte e krahasuar e punes. Tirane: Shtypshkronja llar.

Criminal Code of Republic of Albania.

Directive 2006/54/EC of the European Parliament, 5 July 2006 on implementing the principle of equal opportunities and equal treatment between men and women in relation to employment issues (revised).

International Convention on the Elimination of All Forms of Racial Discrimination. New York, 7 March 1966, acceded in 1994

Karen, E. Lovaas, John, P. Elia, Gust, A. Jep. (2006). LGBT studies and queertheory. USA: Harrington,Park, Press.

Law no.10 221, dated 04.02.2010 "On discrimination protection".

Law no. 8733, dated 24.01.2001.

Labor Code of Rpublic of Albania

Omari, Luan Anastasi, Aurela. (2010). E drejta kushtetuese. Tirane: Luarasi.

\section{Webliography}

http://kmd.al/skedaret/1374673668-Vendim_58.pdf

http://www.mpcs.gov.al/dpshb/images/stories/dpshb/skbgj-rdhbgjdhf2011-2015-180213.pdf

http://www.crca.al/sites/default/files/publications/Strategjia_sektoriale_e_mbrojjes_sociale2007-2013.pdf

http://www.echr.coe.int/Documents/Convention_SQI.pdf

http://www.unmikonline.org/regulations/unmikgazette/03albanian/Ahri/AConEliminationAllFormsDiscriminationAgainstWomen.pdf

http://www.integrimi.gov.al/al/dokumenta/dokumente-strategjike/marreveshja-e-stabilizim-asociimit\&page=1

http://www.pinkembassy.al/sites/default/files/uploade/2011\%20Legjislacioni\%20Nderkombetar\%20dhe\%20Kombetar\%20ne\%20Mbrotje \%20te\%20te\%20Drejtave\%20te\%20Komunitetit\%20LGBT.pdf 